\title{
Relative Host Resistance to Black Spot Disease in Field Pea (Pisum sativum) is Determined by Individual Pathogens
}

Hieu Sy Tran, and Ming Pei You, School of Plant Biology and UWA Institute of Agriculture, Faculty of Science, The University of Western Australia, Crawley, WA 6009, Australia; Tanveer N. Khan, The UWA Institute of Agriculture, Faculty of Science, The University of Western Australia, Crawley, WA 6009, Australia; and Martin J. Barbetti, School of Plant Biology and UWA Institute of Agriculture, Faculty of Science, The University of Western Australia, Crawley WA, 6009, Australia

\begin{abstract}
Tran, H. S., You, M. P., Khan, T. N., and Barbetti, M. J. 2015. Relative host resistance to black spot disease in field pea (Pisum sativum) is determined by individual pathogens. Plant Dis. 99:580-587.

Black spot, also known as Ascochyta blight, is the most important disease on field pea (Pisum sativum). It is caused by a complex of pathogens, the most important of which in Australia include Didymella pinodes, Phoma pinodella, and $P$. koolunga. The relative proportions of these and other component pathogens of the complex fluctuate widely across time and geographic locations in Australia, limiting the ability of breeders to develop varieties with effective resistance to black spot. To address this, 40 field pea genotypes were tested under controlled environment conditions for their individual stem and leaf responses against these three pathogens. Disease severity was calculated as area under disease progress curve (AUDPC), and subsequently converted to mean rank (MR). The overall rank (OR) for each pathogen was used to compare response of genotypes under inoculation with each pathogen. The expressions of host resistance across the field pea genotypes were largely dependent upon the individual test pathogen and whether the test was on stem or leaf. Overall, $P$. koolunga caused most severe stem disease; significantly more severe than either $D$. pinodes or $P$. pinodella. This is the first report of the host resistance identified in field pea to $P$. koolunga; the five genotypes showing highest resistance on stem,

viz. 05P778-BSR-701, ATC 5338, ATC 5345, Dundale, and ATC 866, had AUDPC MR values $<250.4$, while the AUDPC MR values of the 19 genotypes showing the best resistance on leaf was less than 296.8. Two genotypes, ATC 866 and Dundale, showed resistance against $P$. koolunga on both stem and leaf. Against $D$. pinodes, the four and 16 most resistant genotypes on stem and leaf had AUDPC MR values $<111.2$ and $<136.6$, respectively, with four genotypes showing resistance on both stem and leaf including 05P770-BSR-705, Austrian Winter Pea, 06P822-(F5)-BSR-6, and 98107-62E. Against $P$. pinodella, four and eight genotypes showing the best resistance on stem and leaf had AUDPC MR values $<81.3$ and $<221.9$, respectively; three genotypes, viz. 98107-62E, Dundale, and Austrian Winter Pea showed combined resistance on stem and leaf. A few genotypes identified with resistance against two major pathogens of the complex will be of particular significance to breeding programs. These findings explain why field pea varieties arising from breeding programs in Australia fail to display the level or consistency of resistance required against black spot and why there needs to be a wider focus than $D$. pinodes in breeding programs.
\end{abstract}

Field pea, Pisum sativum, is the third most important pulse crop worldwide, after common bean (Phaseolus vulgaris) and chickpeas (Cicer arietinum) (16). There are 7.8 million hectares of field pea annually grown worldwide; in 2012 the total harvested area of field pea was 6.6 million hectares (16). In 2012 Australia ranked at the seventh place in field pea production (342,500 tons), after Canada $(2,803,000$ tons), Russia (1,660,016 tons), China (1,114,000 tons), India (625,000 tons), France (565,322 tons), United State of America (493,150 tons), and Ukraine (351,400 tons) (16).

Black spot on field pea, also known as Ascochyta blight, is a disease complex involving fungi belonging to the phylum Ascomycota including Didymella pinodes (also known as Ascochyta pinodes), A. pisi, and Phoma pinodella (syn. P. medicaginis var. pinodella or $P$. pinodella and formerly known as A. pinodella) $(4,14,28)$. Recently, four additional pathogens have been reported to be associated with black spot, viz. P. koolunga (13), P. herbarum (26), Boerema exigua var. exigua, and $P$. glomerata (44). Black spot is a polycyclic disease (14), in which primary infection usually starts with very small "pinprick" lesions or flecks on the leaf surface of as little as $0.2 \mathrm{~mm}$ after rain events or in humid conditions $(7,37)$. Uninterrupted wet conditions can cause

Corresponding author: M. J. Barbetti, E-mail: martin.barbetti@uwa.edu.au

Accepted for publication 16 October 2014.

http://dx.doi.org/10.1094/PDIS-06-14-0655-RE

(c) 2015 The American Phytopathological Society coalescence of expanding lesions, and eventually senescence of the leaf (4). On leaf, infection caused by ascospores of $D$. pinodes results in many small purple spots, which enlarge, turn brown to black, and assume definite margins and often a zonate appearance under moist conditions (7). Similarly, stem lesions have similar color and elongation, often extending upward and downward from the point of attachment of an infected leaf. Subsequently, lesions become progressively longer and often coalesce to completely girdle stems (7). Under controlled environment conditions, symptoms on foliage of seedlings caused by $P$. koolunga are indistinguishable from those caused by $D$. pinodes (13).

Control strategies for black spot are well documented $(7,14,46-48)$. According to Bretag (7), the best way to control black spot is by avoiding and/or reducing the amount of primary inoculum such as infected seed and infested field pea trash in the soil. Spore production on infested residues can be reduced by either burying or burning infected field pea trash (14,34). In addition, delaying sowing can be used to avoid the main period of peak airborne ascospore showers $(7,14)$. While foliar sprays of fungicides, such as mancozeb or chlorothalonil, can be effective in controlling black spot in many countries $(7,47,48)$, in Australia they are only economical in field pea crops yielding over $2 \mathrm{t} / \mathrm{ha}$ (29). For this reason, foliar fungicides are not applied in most commercial situations in Australia (14), particularly as multiple applications are required to attain significant disease suppression.

Despite numerous studies, there have not been any reports of high level or complete resistance to black spot in the pea germplasm $(20,52,53)$. However, in some commercial varieties and wild pea accessions, there have been reports of partial resistance $(10,19,43,49,52)$. While higher levels of resistance have been identified in wild Pisum 
species, the polygenic nature of resistance has made it challenging for such resistance to be utilized in breeding programs $(11,18,50)$. Breeding for resistance has had only modest success (4), and identifying genes controlling resistance in wild varieties by traditional approaches remains challenging (17). An additional challenge includes the large temporal and spatial changes within the population of pathogens associated with black spot in Western Australia, as recently demonstrated by Tran et al. (42). This is particularly challenging for breeding programs that are largely focused on resistance to $D$. pinodes, ignoring other pathogens of the black spot complex. Deployment of host resistance or fungicides targeting only part of the pathogen complex simply shifts the makeup of the population toward pathogen species least challenged by the host resistance or the particular fungicides (42). The end result is an evolving black spot pathogen complex that remains ahead of breeding progress (42). However, if pathogen populations are monitored, as was recently done in Western Australia (42), it should be possible to identify varieties displaying useful levels of resistance against prevailing individual pathogens within the black spot complex. Success with that approach offers considerable scope to subsequently combine these individual resistances to increase overall resistance to the pea black spot complex. This will make resistance more durable. With that aim, we report a study carried out to determine the relative leaf and stem resistance responses of 40 different field pea genotypes against three important pathogens associated with black spot, viz. $D$. pinodes, $P$. pinodella, and $P$. koolunga.

\section{Materials and Methods}

Germplasm. Seeds of 40 field pea genotypes were supplied by the Department of Agriculture and Food Western Australia and the Australian Temperate Field Crops Collection, Horsham, Victoria. Breeding lines selected randomly from the two sources, along with the cultivars Dundale and Kaspa, were selected to investigate their response individually to the three main pathogens in the black spot complex.

Seedling preparation. Seeds were sown into $4 \times 4 \times 8 \mathrm{~cm}$ pots (one seed per pot) filled with pasteurized potting mix consisting of: $2.5 \mathrm{~m}^{3}$ fine composted pine bark, $1 \mathrm{~m}^{3}$ coco peat, $5 \mathrm{~m}^{3}$ brown river sand, $10 \mathrm{~kg}$ slow release fertilizer Osmoform NXT $22 \mathrm{~N}+2.2 \mathrm{P}_{2} \mathrm{O}_{5}+$ $9.1 \mathrm{~K}_{2} \mathrm{O}+1.2 \mathrm{Mg}+$ trace elements (Everris International B.V.), $10 \mathrm{~kg}$ Dolomite (CalMag), $5 \mathrm{~kg}$ gypsum clay breaker, $5 \mathrm{~kg}$ extra fine limestone, $4 \mathrm{~kg}$ iron hepta sulfate, and $1 \mathrm{~kg}$ iron chelate. Potting mix was pasteurized at $63^{\circ} \mathrm{C}$ for $30 \mathrm{~min}$. Before sowing, $0.1 \mathrm{~g}$ of granulated Rhizobium (Alosca Technologies Pty Ltd) inoculum per pot was placed into the sowing hole to ensure root nodulation. After sowing, pots were initially maintained for 3 weeks in PC2 (physical containment level 2-laboratory issued pursuant to section 90 of the Gene Technology Act 2000) environmentally controlled glasshouse maintained at $20.8^{\circ} \mathrm{C}$, and subsequently subjected to inoculation with pathogens in a controlled environment room (CER).

Pathogen and inoculum production. A single spore isolate of each of the three pathogens was employed in this study as follows: D. pinodes $\mathrm{H} 2012-38$, P pinodella $\mathrm{H} 2012-49$, and $P$. koolunga H2012-81. These isolates came from different areas in Western Australia during a disease survey in 2012 (42); viz. D. pinodes H2012-38 and $P$. pinodella $\mathrm{H} 2012-49$ from diseased field pea foliage at Medina, Western Australia, while P. koolunga H2012-81 was from diseased field pea foliage from Northam, Western Australia. These three isolates were chosen because they were consistently virulent on susceptible genotypes. The pathogens were subcultured onto Coon's agar media (2) from single spore culture. Initially the cultures of $D$. pinodes and $P$. pinodella were maintained at $25^{\circ} \mathrm{C}$ for 3 days, then subjected to UV-C ( $\lambda=200$ to $400 \mathrm{~nm}$ ) light (Phillips TUV 15W) $12 \mathrm{~h}$ on/off for 3 weeks prior to conidia collection. P. koolunga cultures were similarly maintained at $25^{\circ} \mathrm{C}$ for 3 days, but subsequently transferred to an incubator equipped with a black light $(59 \mathrm{~cm}$ length, General Electric F18T8BLB) and white fluorescent tubes $(59 \mathrm{~cm}$ length). Conidia were collected by flooding the cultures with $0.02 \%$ Tween solution, then rubbing the surface with a platinum inoculation loop to release conidia from fruiting bodies. Spore suspensions were then filtered through multiple layers of cheese cloth and the concentration adjusted to $10^{6}$ spores $/ \mathrm{ml}$ using a hemocytometer.
Spore suspensions were used for inoculating plants immediately after preparation.

Inoculation. For this study, a new inoculation procedure was developed. Filter paper discs were impregnated with conidia by soaking into the conidial suspension prior to inoculation and a consequent typical lesion from P. koolunga is shown in Figure 1. This ensured disease developed consistently for all three pathogens and across the two different inoculation sites, viz. leaf and stem and produced similar results as to direct application of conidial suspensions to leaf and stem (H. S. Tran, unpublished). Filter paper discs of $5 \mathrm{~mm}$ diameter were made by punching them out from Whatman No. 1 filter paper and autoclaving before use. Then, for each pathogen isolate, $30 \mathrm{ml}$ of conidia suspension was poured onto a petri dish $(9 \mathrm{~cm}$ diameter $\times 15 \mathrm{~mm}$ height), about 400 paper discs added and soaked in homogenized spore suspension for $1 \mathrm{~h}$, and subsequently placed onto leafs/stipules and internodes surface using fine forceps. The conidia suspension was mixed well before each time a paper disc was picked. On leaf surface, the paper discs were placed directly over the main vein and in the middle longitudinally, while on stem surface, paper discs were placed onto the internode region at approximately $1 \mathrm{~cm}$ above the inoculated leaf/stipule pair. The moist conidia-impregnated paper discs helped maintain high humidity at inoculation sites and were found to be much more reliable compared with inoculation droplets or spray inoculation (H. S. Tran, unpublished). Furthermore, the conidia-impregnated paper discs remained attached on leaf and stem surfaces during the disease incubation period; the paper discs also served as marks for inoculation sites, making it easy to identify the precise inoculation sites at the first disease assessment (3 days after inoculation), particularly at the early stage when only very small disease fleck symptoms appeared. Seedlings were inoculated at 3 weeks after sowing. The exact leaf inoculation sites on each genotype were dependent on the leaf characteristic. Semi leafless genotypes or "afila" had all leaflets transformed into tendrils by the "af" gene (12), while the primitive genotypes had normal leaves including stipules, leaflets, and tendrils. Hence, semileafless genotypes were inoculated on the stipules, whereas all others, including primitive types, were inoculated on the leaflets. On each plant, four leaflets or stipules (third to sixth) and two internodes (second and third) were marked near to the inoculation site with a waterproof permanent marker pen prior to inoculation.

After inoculation, seedlings were maintained for 3 days in plastic boxes ( $77 \mathrm{~cm}$ wide, $475 \mathrm{~cm}$ high, $570 \mathrm{~cm}$ deep) covered with clear polyethylene sheeting held in place by rubber bands. Inoculated plants were maintained in a controlled environment room at $15 / 18^{\circ} \mathrm{C}$ day/night, 12 -h photoperiod, and a light intensity of $380 \mu \mathrm{E} \mathrm{m}^{-2} \mathrm{~s}^{-1}$. To avoid any possible nutrient competition that may indirectly influence the response to the pathogen (8), plants were fertilized weekly with Thrive (NPK $=25: 5: 8.8$, Yates, Australia). To create high humidity conditions inside the boxes $(\geq 95.2 \%)$, a $0.5-\mathrm{cm}$ layer of water was added into the bottom of the boxes prior to placing the seedling trays into them for the duration of the

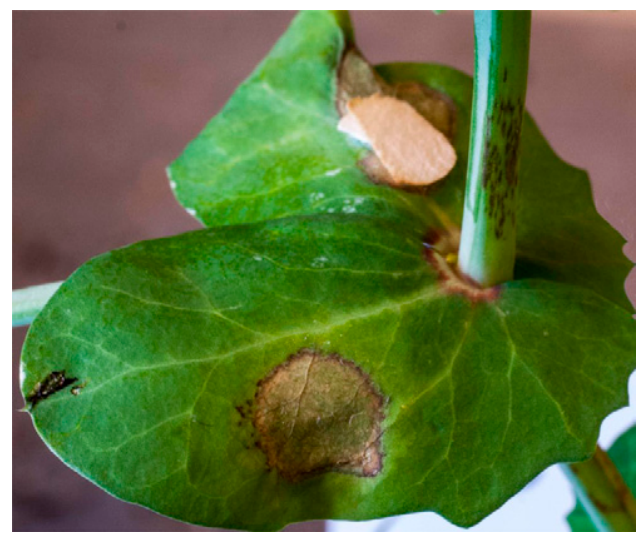

Fig. 1. Black spot symptom on stem and leaf of a susceptible genotype following inoculation made using filter paper discs impregnated with conidia of Phoma koolunga. 
experiments. The seedlings were finely misted with deionized water using a hand sprayer twice to maintain high humidity for the inoculation sites, viz. before covering with the polyethylene sheet and again $24 \mathrm{~h}$ after inoculation.

Disease assessment. Disease assessments were carried out at 3, 7, 10,17 , and 24 days after inoculation (dai). Scoring categories, 0 to 7 (Table 1), as proposed by Wroth (50) and Beeck (5), were employed with some modifications to accommodate the application of conidiaimpregnated paper discs for inoculation.

Experimental design and statistical analyses. Area under disease progress curve (AUDPC) values for each genotype were calculated from independent scores made using $\mathrm{Y}=\sum\left[\left(\mathrm{X}_{\mathrm{i}}+\mathrm{X}_{\mathrm{i}+1}\right) / 2\right]$ $\left(t_{i+1}-t_{i}\right)$, where $Y$ is the AUDPC, $X_{i}$ is leaf/stem disease severity (score) of the "ith" evaluation, $X_{i+1}$ is the leaf/stem score of the " $i+1$ th" evaluation, and " $\left(t_{i+1}-t_{i}\right)$ " is the number of days between two evaluations (9). AUDPC was utilized in that resistance against pathogens in most cultivated crops is present in a quantitative way at varying degrees and hence AUDPC best estimates the accumulated disease severity by assessing the disease severity multiple times (45). Rank transformation of AUDPC values was undertaken using "PROC RANK" in SAS (version 9.3, SAS Institute Inc., Cary, NC) $(24,40)$, in which ranks were assigned ascendingly for each AUDPC value in the data set (24). Tied values were given the smallest of the corresponding ranks (24). AUDPC mean ranks were tabulated to show responses of tested genotypes affected by three pathogens individually.

A completely randomized design with four replications was used. Each replication was mean of disease score of the four leaves or two internodes inoculated on one plant. All experiments were conducted in nonchanged conditions and were fully repeated at least once. The homogeneity of initial and repeat experiments was assessed using AUDPC values for "two samples $t$ test for mean" and in addition, MannWhitney U nonparametric test was also used based on transformed AUDPC mean ranks. These tests showed no significant difference $(P>0.05)$ between initial and repeated experiment data; hence, data sets from initial and repeat experiments were pooled, reanalyzed as a single data set. A nonparametric test, ANOVA-type statistic (ATS) in SAS as described by Shah and Madden (40), was employed to analyze the data. In brief, "PROC RANK" in SAS was used to obtain the ranks for all AUDPC data as mentioned previously, then both one- and two-way factorial mode of ATS were implemented on the ranks using "PROC MIXED" in SAS. Estimated relative treatment effect (ERTE) values at $\alpha=0.05$ and their standard error, calculated in SAS, were used to compare reactions of different genotypes to the three black spot pathogens. Spearman's rank correlation was employed to examine the relationship among disease on leaf versus stem caused by each pathogen.

\section{Results}

D. pinodes. Area under disease progress curve rank mean (AUDPC $\mathrm{MR}$ ) of 40 genotypes inoculated with $D$. pinodes were significantly different $(P<0.001)$ on both stem and leaf. Against $D$. pinodes on

Table 1. Disease assessment scores utilized to rate black spot disease on stem and leaf of field pea

\begin{tabular}{|c|c|}
\hline Lesions on leaflets/stipules & Lesions on stems \\
\hline $0=$ no symptom & $0=$ no symptom \\
\hline $1=\leq 5$ disease flecks & $1=\leq 5$ disease flecks \\
\hline $2=>5$ disease flecks & $2=>5$ disease flecks \\
\hline $\begin{array}{l}3=\text { lesions coalesced across } 50 \% \\
\text { area of the inoculation site }\end{array}$ & $\begin{array}{l}3=\text { lesion coalesced across } 50 \% \text { area } \\
\text { of the inoculation site }\end{array}$ \\
\hline $\begin{array}{l}4=\text { lesion coalesced across } 100 \% \\
\text { of inoculation site in combination } \\
\text { with senescence }<25 \% \text { of leaflet } \\
\text { or stipule area }\end{array}$ & $\begin{array}{l}4 \text { = lesion coalesced across } 100 \% \text { of } \\
\text { inoculation site longitudinally }(5 \mathrm{~mm} \\
\text { approx.) }\end{array}$ \\
\hline $\begin{array}{l}5=\text { leaf senescence }>25 \text { to } 50 \% \text { of } \\
\text { leaflet or stipule area }\end{array}$ & $5=$ necrotic patch extended $>5-10 \mathrm{~mm}$ \\
\hline $\begin{array}{l}6=\text { leaf senescence }>50 \text { to } 75 \% \text { of } \\
\text { leaflet or stipule area }\end{array}$ & $6=$ necrotic patch extended $>10 \mathrm{~mm}$ \\
\hline $\begin{array}{l}7=\text { leaf senescence }>75 \% \text { of leaflet } \\
\text { or stipule area }\end{array}$ & $7=$ stem girdled and collapsed \\
\hline
\end{tabular}

stem, AUDPC MR across the 40 genotypes ranged from 68.0 to 407.5 with a mean of 244.1 (Table 2), ATC 2312 being the most resistant genotype (AUDPC MR $=68.0$, Overall rank $-\mathrm{OR}=1$, Estimated relative treatment effect $-\mathrm{ERTE}=0.11 \pm 0.039$ ) followed by $35-2 \mathrm{C}$, 05P770-BSR-705, and ATC 864. On leaf, AUDPC MR changed from 48.8 to 521.8 with a mean of 235.0 (Table 3 ); the 16 most resistant genotypes had AUDPC MR < 136.6 with 06P822-(F5)-BSR-6 (AUDPC $\mathrm{MR}=48.8, \mathrm{OR}=1, \mathrm{ERTE}=0.08 \pm 0.041)$ being the most resistant Four genotypes showed high level of resistance against $D$. pinodes for both stem and leaf, viz. 05P770-BSR-705 (AUDPC MR = 106.9, $\mathrm{OR}=3$ on stem and AUDPC MR $=70.1, \mathrm{OR}=5$ on leaf), Austrian Winter Pea (AUDPC MR $=131.6, \mathrm{OR}=5$ on stem and AUDPC $\mathrm{MR}=77.6, \mathrm{OR}=7$ on leaf), 06P822-(F5)-BSR-6 (AUDPC MR = 137.4, $\mathrm{OR}=6$ on stem and AUDPC MR $=48.8, \mathrm{OR}=1$ on leaf), and 98107-62E (AUDPC MR $=150.8$, OR $=8$ on stem and AUDPC $\mathrm{MR}=56.7, \mathrm{OR}=3$ on leaf).

$P$. koolunga. Against $P$. koolunga, there were significant differences across genotypes in relation to either leaf or stem AUDPC MR $(P<0.001)$. On stem, AUDPC MR varied from 114.4 to 535.8 with a mean of 410.2 (Table 2), and five most resistant genotypes had AUDPC MR ranging from $114.4(\mathrm{ERTE}=0.19 \pm 0.127$ ) to 250.4 $($ ERTE $=0.35 \pm 0.189)$, viz. 05P778-BSR-701, ATC 5338, ATC 5345, Dundale, and ATC 866. On leaf, the AUDPC MR values ranged from 155.9 to 593.1 with a mean of 340.6; the 19 most resistant genotypes had AUDPC MR from 155.9 (ERTE $=0.25 \pm 0.173$ ) to $296.8($ ERTE $=0.48 \pm 0.146)$ (Table 3$)$, with ATC 866 the most resistant (AUDPC MR $=155.9$ ). Two genotypes showed resistance against $P$. koolunga on both stem and leaf, viz. ATC 866 (AUDPC $\mathrm{MR}=250.4, \mathrm{OR}=5$ and $\mathrm{AUDPC} \mathrm{MR}=155.9, \mathrm{OR}=1$, on stem and leaf, respectively) and Dundale (AUDPC MR $=216.8, \mathrm{OR}=4$ and AUDPC MR $=230.6, \mathrm{OR}=6$, on stem and leaf, respectively).

$P$. pinodella. Against $P$. pinodella, there were significant differences in AUDPC MR of genotypes in relation to either leaf or stem disease $(P<0.001)$. On stem, AUDPC MR ranged from 64.3 to 559.8 (Table 2). The four genotypes with best resistance had AUDPC MR values from $64.3($ ERTE $=0.1 \pm 0.07)$ to $81.3($ ERTE $=0.13 \pm 0.023)$, with the most resistant genotype being ATC 866 followed by Dundale, 05P803-BSR-701, and ATC 864. On leaf, AUDPC MR ranged from 136.8 to 539.6, with a mean of 343.9 (Table 3). The eight genotypes with the greatest resistance against $P$. pinodella had AUDPC MR from $136.8($ ERTE $=0.22 \pm 0.063)$ to $221.9($ ERTE $=0.36 \pm$ 0.098). Resistance on both leaf and stem was shown for three genotypes, viz. 98107-62E (AUDPC MR $=134.7, \mathrm{OR}=6$ on stem and AUDPC MR $=144.2$, OR $=2$ on leaf), Dundale (AUDPC MR = $70.8, \mathrm{OR}=2$ on stem and AUDPC MR $=221.9, \mathrm{OR}=8$ on leaf), and Austrian Winter Pea (AUDPC MR $=156.3, \mathrm{OR}=8$ on stem and AUDPC MR $=214.2$, OR $=7$ on leaf).

Leaf versus stem. When averaged across all three pathogens, there were significant differences $(P<0.001)$ across the 40 genotypes to each of the three pathogens for both stem and leaf. On stem, mean AUDPC MR of genotypes ranged from 162.5 to 462.1 (Table 2) where eight genotypes with the lowest AUDPC MR ranged from $162.5($ ERTE $=0.26 \pm 0.069)$ to $234.4($ ERTE $=0.38 \pm 0.058)$. On leaf, AUDPC MR ranged from 141.6 to 527.6 with the lowest AUDPC MR values of 10 genotypes ranging from 141.6 (ERTE = $0.23 \pm 0.063)$ to $212.3($ ERTE $=0.35 \pm 0.078)($ Table 3$)$.

Virulence of pathogens. There were significant differences $(P<$ $0.001)$ among the three pathogens in their virulence on stem and on leaf. P. koolunga was the most virulent on stem, with a significantly higher $(P<0.001)$ AUDPC MR $(410.2$, ERTE $=0.67 \pm$ 0.015 ) than that of $D$. pinodes $(\mathrm{AUDPC} \mathrm{MR}=244.1$, ERTE $=$ $0.4 \pm 0.014)$ and $P$. pinodella $($ AUDPC MR $=265.3$, ERTE $=0.43 \pm$ 0.016) (Table 2). There was no significant difference in AUDPC MR between $D$. pinodes and $P$. pinodella on stem. On leaf, $P$. koolunga $($ AUDPC MR $=340.6$, ERTE $=0.56 \pm 0.015)$ and $P$. pinodella (AUDPC MR $=343.9$, ERTE $=0.56 \pm 0.016)$ were significantly more virulent $(P<0.001)$ than $D$. pinodes $($ AUDPC $\mathrm{MR}=235.0, \mathrm{ERTE}=$ $0.38 \pm 0.017$ ) (Table 3 ).

Multiple resistances. For both leaf and stem disease, there were significant interactions $(P<0.001)$ (Table 2 and 3$)$ between genotypes and 
pathogens. Relatively few genotypes showed resistance against any two of the three pathogens on leaf or on stem. Eight genotypes showed resistance against two pathogens on stem, viz. Dundale, ATC 866, 35-2C, ATC 5345 ( $P$. koolunga and $P$. pinodella), 05P778-BSR-701 (D. pinodes and $P$. koolunga), ATC 864, Austrian Winter Pea, and 98107-62E (D. pinodes and $P$. pinodella). Seven genotypes showed resistance against two pathogens on leaf, viz. Dundale ( $P$. koolunga and $P$. pinodella), 06P822-(F5)-BSR-7, 05P773-BSR-706, M 330-6 (D. pinodes and P. koolunga), Austrian Winter Pea, 05P803-BSR-701, and 98107-62E (D. pinodes and $P$. pinodella). Two genotypes, viz. 35-2C and 05P773BSR-706, showed resistance to all three pathogens on stem and leaf, respectively.

Most genotypes only showed resistance to a single pathogen or were susceptible to all three pathogens on stem as well as on leaf. On stem, an example of a genotype with resistance to one pathogen but very susceptible to the other two is 05P770-BSR-705, which was among the three most resistant genotypes to $D$. pinodes (AUDPC MR $=106.9$, $\mathrm{OR}=3$ ), but was susceptible to both $P$. koolunga $($ AUDPC MR = 459.5, $\mathrm{OR}=27)$ and $P$. pinodella $(\mathrm{AUDPC} \mathrm{MR}=350.0, \mathrm{OR}=31)$. Similarly, on leaf, 06P822-(F5)-BSR-6 was the most resistant genotype against $D$. pinodes (AUDPC MR $=48.8, \mathrm{OR}=1$ ), but was very susceptible to $P$. koolunga (AUDPC MR $=415.6$, $\mathrm{OR}=34$ ), and also susceptible to $P$. pinodella (AUDPC MR $=328.0, \mathrm{OR}=17$ ).

\section{Discussion}

This study has identified important genotypes with resistance on both leaf and stem and others with leaf or stem resistance against each individual pathogen; resistance against $P$. koolunga on leaf or on

Table 2. Response on stem for 40 field pea (Pisum sativum) genotypes inoculated with Didymella pinodes, Phoma koolunga, and $P$. pinodella. Disease levels were expressed as mean rank of area under disease progress curve (AUDPC) values

\begin{tabular}{|c|c|c|c|c|c|c|c|c|c|c|c|}
\hline \multirow[b]{2}{*}{ Genotypes } & \multicolumn{3}{|c|}{ Didymella pinodes } & \multicolumn{3}{|c|}{ Phoma koolunga } & \multicolumn{3}{|c|}{ P. pinodella } & \multicolumn{2}{|c|}{ Means } \\
\hline & $\begin{array}{c}\text { AUDPC } \\
\text { mean } \\
\text { rank }\end{array}$ & $\begin{array}{c}\text { ERTE }^{\mathrm{a}} \\
(\mathrm{SE})^{\mathrm{b}}\end{array}$ & $\begin{array}{c}\text { Overall } \\
\text { rank }\end{array}$ & $\begin{array}{c}\text { AUDPC } \\
\text { mean } \\
\text { rank }\end{array}$ & $\begin{array}{c}\text { ERTE }^{\mathrm{a}} \\
(\mathrm{SE})^{\mathrm{b}}\end{array}$ & $\begin{array}{c}\text { Overall } \\
\text { rank }\end{array}$ & $\begin{array}{c}\text { AUDPC } \\
\text { mean } \\
\text { rank }\end{array}$ & $\begin{array}{c}\text { ERTE }^{a} \\
(\mathrm{SE})^{\mathrm{b}}\end{array}$ & $\begin{array}{c}\text { Overall } \\
\text { rank }\end{array}$ & $\begin{array}{c}\text { AUDPC } \\
\text { mean } \\
\text { rank }\end{array}$ & $\begin{array}{c}\text { ERTE }^{\mathrm{a}} \\
(\mathrm{SE})^{\mathrm{b}}\end{array}$ \\
\hline Dundale & 199.9 & $0.33(0.081)$ & 14 & 216.8 & $0.35(0.189)$ & 4 & 70.8 & $0.11(0.017)$ & 2 & 162.5 & $0.26(0.069)$ \\
\hline ATC 866 & 192.0 & $0.31(0.130)$ & 13 & 250.4 & $0.41(0.160)$ & 5 & 64.3 & $0.10(0.070)$ & 1 & 168.9 & $0.28(0.075)$ \\
\hline $35-2 \mathrm{C}$ & 91.6 & $0.15(0.014)$ & 2 & 326.0 & $0.53(0.155)$ & 7 & 113.8 & $0.19(0.061)$ & 5 & 177.1 & $0.29(0.072)$ \\
\hline ATC 5345 & 256.9 & $0.42(0.108)$ & 21 & 161.3 & $0.26(0.125)$ & 3 & 169.3 & $0.28(0.237)$ & 10 & 195.8 & $0.32(0.089)$ \\
\hline 05P778-BSR-701 & 150.8 & $0.25(0.027)$ & 7 & 114.4 & $0.19(0.127)$ & 1 & 326.0 & $0.53(0.041)$ & 25 & 197.0 & $0.32(0.061)$ \\
\hline ATC 864 & 111.2 & $0.18(0.066)$ & 4 & 464.9 & $0.76(0.111)$ & 30 & 80.6 & $0.13(0.066)$ & 3 & 218.9 & $0.36(0.074)$ \\
\hline ATC 5338 & 262.3 & $0.43(0.094)$ & 22 & 134.8 & $0.22(0.175)$ & 2 & 281.4 & $0.46(0.167)$ & 20 & 226.1 & $0.37(0.084)$ \\
\hline Austrian Winter Pea & 131.6 & $0.21(0.047)$ & 5 & 391.4 & $0.64(0.081)$ & 15 & 156.3 & $0.25(0.089)$ & 8 & 226.4 & $0.37(0.056)$ \\
\hline $98107-62 \mathrm{E}$ & 150.8 & $0.25(0.041)$ & 8 & 417.6 & $0.68(0.108)$ & 18 & 134.7 & $0.22(0.038)$ & 6 & 234.4 & $0.38(0.058)$ \\
\hline 05P803-BSR-701 & 219.8 & $0.36(0.120)$ & 17 & 473.6 & $0.77(0.017)$ & 33 & 81.3 & $0.13(0.023)$ & 4 & 258.2 & $0.42(0.087)$ \\
\hline ATC 2312 & 68.0 & $0.11(0.039)$ & 1 & 496.0 & $0.81(0.054)$ & 35 & 238.0 & $0.39(0.176)$ & 16 & 267.3 & $0.44(0.103)$ \\
\hline ATC 865 & 264.4 & $0.43(0.085)$ & 23 & 439.3 & $0.72(0.063)$ & 23 & 155.4 & $0.25(0.043)$ & 7 & 286.3 & $0.47(0.067)$ \\
\hline 06P821-(F5)-BSR-4 & 277.4 & $0.45(0.087)$ & 28 & 376.9 & $0.61(0.062)$ & 11 & 231.8 & $0.38(0.162)$ & 15 & 295.3 & $0.48(0.066)$ \\
\hline 06P822-(F5)-BSR-6 & 137.4 & $0.22(0.036)$ & 6 & 498.3 & $0.81(0.069)$ & 36 & 275.0 & $0.45(0.148)$ & 19 & 303.5 & $0.50(0.088)$ \\
\hline 05P770-BSR-705 & 106.9 & $0.17(0.077)$ & 3 & 459.5 & $0.75(0.111)$ & 27 & 350.0 & $0.57(0.076)$ & 31 & 305.5 & $0.50(0.085)$ \\
\hline ATC 859 & 321.6 & $0.52(0.083)$ & 33 & 369.1 & $0.60(0.137)$ & 10 & 225.8 & $0.37(0.070)$ & 13 & 305.5 & $0.50(0.058)$ \\
\hline 06P830-(F5)-BSR-1 & 303.8 & $0.50(0.144)$ & 31 & 379.1 & $0.62(0.107)$ & 12 & 243.6 & $0.40(0.056)$ & 17 & 308.8 & $0.50(0.063)$ \\
\hline 00P097-006 & 327.6 & $0.53(0.116)$ & 34 & 266.1 & $0.43(0.085)$ & 6 & 340.8 & $0.56(0.098)$ & 27 & 311.5 & $0.51(0.055)$ \\
\hline 06P847-(F5)-BSR-3 & 247.4 & $0.40(0.137)$ & 19 & 366.4 & $0.60(0.091)$ & 9 & 324.6 & $0.53(0.076)$ & 24 & 312.8 & $0.51(0.060)$ \\
\hline 06P822-(F5)-BSR-7 & 163.4 & $0.27(0.072)$ & 12 & 423.0 & $0.69(0.106)$ & 20 & 359.0 & $0.59(0.087)$ & 32 & 315.1 & $0.51(0.071)$ \\
\hline ATC 5336 & 407.5 & $0.67(0.101)$ & 40 & 380.3 & $0.62(0.140)$ & 13 & 160.5 & $0.26(0.073)$ & 9 & 316.1 & $0.52(0.069)$ \\
\hline Kaspa & 284.5 & $0.46(0.051)$ & 29 & 467.9 & $0.76(0.044)$ & 31 & 207.2 & $0.34(0.098)$ & 11 & 319.9 & $0.52(0.052)$ \\
\hline 00P040-BSR-707 & 206.4 & $0.34(0.157)$ & 16 & 456.3 & $0.74(0.191)$ & 26 & 298.4 & $0.49(0.039)$ & 23 & 320.3 & $0.52(0.090)$ \\
\hline M 330-6 & 161.6 & $0.26(0.070)$ & 11 & 469.9 & $0.77(0.058)$ & 32 & 342.3 & $0.56(0.109)$ & 28 & 324.6 & $0.53(0.075)$ \\
\hline 06P820-(F5)-BSR-1 & 274.1 & $0.45(0.060)$ & 26 & 414.6 & $0.68(0.103)$ & 17 & 287.0 & $0.47(0.043)$ & 21 & 325.3 & $0.53(0.046)$ \\
\hline 05P770-BSR-707 & 274.2 & $0.45(0.092)$ & 27 & 495.2 & $0.81(0.052)$ & 34 & 225.3 & $0.37(0.086)$ & 12 & 331.5 & $0.54(0.058)$ \\
\hline ATC 5337 & 158.3 & $0.26(0.043)$ & 9 & 464.8 & $0.76(0.088)$ & 29 & 398.3 & $0.65(0.187)$ & 33 & 340.4 & $0.56(0.090)$ \\
\hline 06P830-(F5)-BSR-4 & 271.6 & $0.44(0.121)$ & 25 & 326.9 & $0.53(0.174)$ & 8 & 425.8 & $0.69(0.152)$ & 35 & 341.4 & $0.56(0.084)$ \\
\hline 06P851-(F5)-BSR-10 & 247.0 & $0.40(0.067)$ & 18 & 455.0 & $0.74(0.090)$ & 25 & 329.6 & $0.54(0.135)$ & 26 & 343.9 & $0.56(0.068)$ \\
\hline ATC 5347 & 350.9 & $0.57(0.083)$ & 36 & 439.8 & $0.72(0.153)$ & 24 & 250.6 & $0.41(0.087)$ & 18 & 347.1 & $0.57(0.066)$ \\
\hline 06P817-(F5)-BSR-2 & 161.1 & $0.26(0.073)$ & 10 & 432.3 & $0.71(0.101)$ & 21 & 468.8 & $0.77(0.164)$ & 36 & 354.0 & $0.58(0.091)$ \\
\hline ATC 36 & 314.0 & $0.51(0.077)$ & 32 & 535.8 & $0.87(0.042)$ & 40 & 225.9 & $0.37(0.080)$ & 14 & 358.6 & $0.59(0.057)$ \\
\hline WAPEA2211 & 267.7 & $0.44(0.023)$ & 24 & 517.1 & $0.84(0.047)$ & 38 & 291.9 & $0.48(0.091)$ & 22 & 358.9 & $0.59(0.050)$ \\
\hline 06P817-(F5)-BSR-3 & 256.6 & $0.42(0.103)$ & 20 & 502.0 & $0.82(0.046)$ & 37 & 342.5 & $0.56(0.108)$ & 29 & 367.0 & $0.60(0.068)$ \\
\hline 05P773-BSR-706 & 358.1 & $0.58(0.083)$ & 37 & 400.5 & $0.65(0.197)$ & 16 & 349.4 & $0.57(0.157)$ & 30 & 369.3 & $0.60(0.080)$ \\
\hline 06P851-(F5)-BSR-5 & 359.6 & $0.59(0.048)$ & 38 & 389.0 & $0.63(0.045)$ & 14 & 411.0 & $0.67(0.056)$ & 34 & 386.5 & $0.63(0.031)$ \\
\hline 06P821-(F5)-BSR-2 & 205.1 & $0.33(0.062)$ & 15 & 464.3 & $0.76(0.094)$ & 28 & 525.6 & $0.86(0.078)$ & 39 & 398.3 & $0.65(0.079)$ \\
\hline 06P851-(F5)-BSR-12 & 335.4 & $0.55(0.064)$ & 35 & 420.1 & $0.69(0.088)$ & 19 & 492.3 & $0.80(0.053)$ & 38 & 415.9 & $0.68(0.049)$ \\
\hline 06P830-(F5)-BSR-5 & 292.5 & $0.48(0.097)$ & 30 & 530.0 & $0.87(0.016)$ & 39 & 469.5 & $0.77(0.107)$ & 37 & 430.7 & $0.70(0.066)$ \\
\hline 06P851-(F5)-BSR-9 & 387.8 & $0.63(0.080)$ & 39 & 438.9 & $0.72(0.064)$ & 22 & 559.8 & $0.91(0.036)$ & 40 & 462.1 & $0.75(0.048)$ \\
\hline Pathogen mean rank & 244.1 & & & 410.2 & & & 265.3 & & & & \\
\hline ERTE (SE) & $0.4(0.014)$ & & & $0.67(0.015)$ & & & $0.43(0.016)$ & & & & \\
\hline \multicolumn{12}{|c|}{ Analysis of variance-type statistic, one-way } \\
\hline & & $\mathrm{F}$ & $P$ value & & & & & & & & \\
\hline Significance among p & thogens & 64.41 & $<0.0001$ & & & & & & & & \\
\hline Significance among ge & notypes & 2.69 & $<0.0001$ & & & & & & & & \\
\hline \multicolumn{12}{|c|}{ Analysis of variance-type statistic, two-way } \\
\hline & & $F$ & $P$ value & & & & & & & & \\
\hline Overall pathogens (1) & & 72.58 & $<0.0001$ & & & & & & & & \\
\hline Genotypes (2) & & 3.98 & $<0.0001$ & & & & & & & & \\
\hline Pathogens $\times$ Genotype & & 2.52 & $<0.0001$ & & & & & & & & \\
\hline
\end{tabular}

a ERTE: Estimated relative treatment effect at $\alpha=0.05$.

b SE: Standard error. 
stem is being reported for the first time. Importantly, this study is the first to identify genotypes, albeit few, with combined resistance against two major pathogens of the complex with significant implications to the breeding for resistance. Further, this study has highlighted genotypes susceptible to all three pathogens that are best culled from breeding programs.

In general, most genotypes expressed resistance differentially to each of the individual pathogens in the complex, and as confirmed by a strong interaction between genotypes with pathogens. While there were very few genotypes with resistance to two pathogens on leaf and/or stem, most showed resistance to a single pathogen and susceptibility to the other two, even for genotypes that displayed high level resistance to one particular fungus. For instance, 05P770-BSR705 ranked third in resistance to $D$. pinodes on stem was susceptible to both $P$. koolunga, ranked 27, and $P$. pinodella, ranked 31 . Similarly, 06P822-(F5)-BSR-6, which was the most resistant genotype against $D$. pinodes on leaf, was very susceptible to $P$. koolunga, ranked 34 , and $P$. pinodella, ranked 17 . This is perhaps not surprising as sources of field pea resistance against black spot and to $D$. pinodes are very limited, with no major resistance genes having been identified (23). It is generally accepted that resistance to black spot is polygenic and there is no pathotype specificity $(38,39,51)$. While our study and other investigations (H. S. Tran, unpublished) support these conclusions, others suggest the presence of distinct pathotypes could exist within $D$. pinodes (2). Furthermore, involvement of at least three major pathogens within the black spot complex in Australia adds to the complexity of identifying resistance. So far, there has only been a single study in Australia by Ali et al. (2) on resistance

Table 3. Response on leaf for 40 field pea (Pisum sativum) genotypes inoculated with Didymella pinodes, Phoma koolunga, and $P$. pinodella. Disease levels were expressed as mean rank of area under disease progress curve (AUDPC) values

\begin{tabular}{|c|c|c|c|c|c|c|c|c|c|c|c|}
\hline \multirow[b]{2}{*}{ Genotypes } & \multicolumn{3}{|c|}{ Didymella pinodes } & \multicolumn{3}{|c|}{ Phoma koolunga } & \multicolumn{3}{|c|}{ P. pinodella } & \multicolumn{2}{|c|}{ Means } \\
\hline & $\begin{array}{c}\text { AUDPC } \\
\text { mean } \\
\text { rank }\end{array}$ & $\begin{array}{l}\text { ERTE }^{\mathrm{a}} \\
(\mathrm{SE})^{\mathrm{b}}\end{array}$ & $\begin{array}{c}\text { Overall } \\
\text { rank }\end{array}$ & $\begin{array}{c}\text { AUDPC } \\
\text { mean } \\
\text { rank }\end{array}$ & $\begin{array}{l}\text { ERTE }^{\mathrm{a}} \\
(\mathrm{SE})^{\mathrm{b}}\end{array}$ & $\begin{array}{c}\text { Overall } \\
\text { rank }\end{array}$ & $\begin{array}{c}\text { AUDPC } \\
\text { mean } \\
\text { rank }\end{array}$ & $\begin{array}{l}\text { ERTE }^{\mathrm{a}} \\
(\mathrm{SE})^{\mathrm{b}}\end{array}$ & $\begin{array}{c}\text { Overall } \\
\text { rank }\end{array}$ & $\begin{array}{c}\text { AUDPC } \\
\text { mean } \\
\text { rank }\end{array}$ & $\begin{array}{l}\text { ERTE }^{\mathrm{a}} \\
(\mathrm{SE})^{\mathrm{b}}\end{array}$ \\
\hline 05P773-BSR-706 & 56.8 & $0.09(0.031)$ & 4 & 157.1 & $0.26(0.111)$ & 2 & 211.0 & $0.34(0.142)$ & 6 & 141.6 & $0.23(0.063)$ \\
\hline Kaspa & 96.1 & $0.16(0.035)$ & 11 & 249.1 & $0.41(0.036)$ & 11 & 136.8 & $0.22(0.063)$ & 1 & 160.7 & $0.26(0.033)$ \\
\hline $98107-62 \mathrm{E}$ & 56.7 & $0.09(0.025)$ & 3 & 333.2 & $0.54(0.069)$ & 24 & 144.2 & $0.23(0.045)$ & 2 & 178.0 & $0.29(0.047)$ \\
\hline 05P770-BSR-707 & 104.6 & $0.17(0.049)$ & 13 & 297.1 & $0.48(0.035)$ & 20 & 163.5 & $0.27(0.047)$ & 3 & 188.4 & $0.31(0.036)$ \\
\hline 05P770-BSR-705 & 70.1 & $0.11(0.050)$ & 5 & 250.0 & $0.41(0.080)$ & 12 & 254.5 & $0.42(0.029)$ & 12 & 191.5 & $0.31(0.051)$ \\
\hline 05P803-BSR-701 & 83.1 & $0.14(0.036)$ & 9 & 296.8 & $0.48(0.146)$ & 19 & 196.0 & $0.32(0.075)$ & 4 & 192.0 & $0.31(0.066)$ \\
\hline Austrian Winter Pea & 77.6 & $0.13(0.029)$ & 7 & 327.4 & $0.53(0.068)$ & 23 & 214.2 & $0.35(0.103)$ & 7 & 206.4 & $0.34(0.052)$ \\
\hline 06P821-(F5)-BSR-4 & 120.3 & $0.20(0.060)$ & 14 & 189.4 & $0.31(0.157)$ & 3 & 317.0 & $0.52(0.104)$ & 14 & 208.9 & $0.34(0.071)$ \\
\hline $35-2 \mathrm{C}$ & 103.1 & $0.17(0.019)$ & 12 & 194.6 & $0.32(0.114)$ & 4 & 329.0 & $0.54(0.047)$ & 18 & 208.9 & $0.34(0.059)$ \\
\hline M 330-6 & 51.8 & $0.08(0.018)$ & 2 & 224.6 & $0.37(0.131)$ & 5 & 360.4 & $0.59(0.090)$ & 22 & 212.3 & $0.35(0.078)$ \\
\hline Dundale & 193.6 & $0.32(0.063)$ & 20 & 230.6 & $0.38(0.141)$ & 6 & 221.9 & $0.36(0.098)$ & 8 & 215.4 & $0.35(0.056)$ \\
\hline 06P822-(F5)-BSR-7 & 72.0 & $0.12(0.027)$ & 6 & 241.6 & $0.39(0.144)$ & 7 & 346.5 & $0.57(0.105)$ & 20 & 220.0 & $0.36(0.077)$ \\
\hline 06P820-(F5)-BSR-1 & 139.6 & $0.23(0.055)$ & 17 & 345.6 & $0.56(0.077)$ & 25 & 200.8 & $0.33(0.052)$ & 5 & 228.7 & $0.37(0.044)$ \\
\hline 05P778-BSR-701 & 131.3 & $0.21(0.099)$ & 15 & 245.0 & $0.40(0.047)$ & 9 & 327.5 & $0.53(0.122)$ & 16 & 234.6 & $0.38(0.063)$ \\
\hline ATC 866 & 246.4 & $0.40(0.203)$ & 25 & 155.9 & $0.25(0.173)$ & 1 & 324.0 & $0.53(0.155)$ & 15 & 242.1 & $0.39(0.098)$ \\
\hline 00P040-BSR-707 & 136.6 & $0.22(0.106)$ & 16 & 356.6 & $0.58(0.139)$ & 28 & 265.4 & $0.43(0.059)$ & 13 & 252.9 & $0.41(0.071)$ \\
\hline ATC 2312 & 245.4 & $0.40(0.165)$ & 24 & 284.8 & $0.46(0.075)$ & 17 & 232.4 & $0.38(0.044)$ & 10 & 254.2 & $0.41(0.057)$ \\
\hline 06P822-(F5)-BSR-6 & 48.8 & $0.08(0.041)$ & 1 & 415.6 & $0.68(0.120)$ & 34 & 328.0 & $0.54(0.108)$ & 17 & 264.1 & $0.43(0.091)$ \\
\hline WAPEA2211 & 157.9 & $0.26(0.034)$ & 18 & 415.9 & $0.68(0.040)$ & 35 & 228.0 & $0.37(0.084)$ & 9 & 267.3 & $0.44(0.048)$ \\
\hline ATC 864 & 216.3 & $0.35(0.136)$ & 23 & 367.1 & $0.6(0.044)$ & 31 & 247.6 & $0.40(0.077)$ & 11 & 277.0 & $0.45(0.055)$ \\
\hline 06P817-(F5)-BSR-3 & 250.9 & $0.41(0.155)$ & 26 & 268.3 & $0.44(0.085)$ & 13 & 352.6 & $0.58(0.072)$ & 21 & 290.6 & $0.47(0.061)$ \\
\hline 06P817-(F5)-BSR-2 & 82.5 & $0.13(0.067)$ & 8 & 437.5 & $0.71(0.057)$ & 36 & 366.3 & $0.60(0.136)$ & 23 & 295.4 & $0.48(0.089)$ \\
\hline 06P830-(F5)-BSR-4 & 205.5 & $0.33(0.169)$ & 22 & 291.5 & $0.48(0.128)$ & 18 & 415.9 & $0.68(0.112)$ & 25 & 304.3 & $0.50(0.083)$ \\
\hline 06P830-(F5)-BSR-5 & 169.5 & $0.28(0.161)$ & 19 & 305.3 & $0.50(0.042)$ & 21 & 469.5 & $0.77(0.052)$ & 30 & 314.8 & $0.51(0.079)$ \\
\hline ATC 5337 & 93.0 & $0.15(0.067)$ & 10 & 351.1 & $0.57(0.154)$ & 26 & 530.9 & $0.87(0.084)$ & 39 & 325.0 & $0.53(0.104)$ \\
\hline 00P097-006 & 337.8 & $0.55(0.204)$ & 29 & 241.9 & $0.39(0.135)$ & 8 & 461.3 & $0.75(0.066)$ & 29 & 347.0 & $0.57(0.087)$ \\
\hline ATC 865 & 390.0 & $0.64(0.101)$ & 32 & 353.9 & $0.58(0.051)$ & 27 & 335.8 & $0.55(0.096)$ & 19 & 359.9 & $0.59(0.046)$ \\
\hline 06P821-(F5)-BSR-2 & 203.8 & $0.33(0.161)$ & 21 & 365.6 & $0.60(0.048)$ & 30 & 511.5 & $0.83(0.052)$ & 37 & 360.3 & $0.59(0.080)$ \\
\hline ATC 5345 & 327.1 & $0.53(0.044)$ & 28 & 248.5 & $0.41(0.097)$ & 10 & 505.8 & $0.83(0.06)$ & 36 & 360.5 & $0.59(0.064)$ \\
\hline 06P851-(F5)-BSR-10 & 361.8 & $0.59(0.067)$ & 30 & 277.3 & $0.45(0.073)$ & 14 & 451.4 & $0.74(0.037)$ & 28 & 363.5 & $0.59(0.047)$ \\
\hline ATC 5338 & 287.3 & $0.47(0.122)$ & 27 & 397.8 & $0.65(0.190)$ & 32 & 413.8 & $0.68(0.118)$ & 24 & 366.3 & $0.60(0.081)$ \\
\hline 06P851-(F5)-BSR-5 & 428.1 & $0.70(0.099)$ & 34 & 282.0 & $0.46(0.044)$ & 16 & 431.5 & $0.70(0.047)$ & 26 & 380.5 & $0.62(0.049)$ \\
\hline 06P851-(F5)-BSR-9 & 375.5 & $0.61(0.096)$ & 31 & 278.1 & $0.45(0.038)$ & 15 & 492.6 & $0.80(0.070)$ & 33 & 382.1 & $0.62(0.057)$ \\
\hline 06P830-(F5)-BSR-1 & 432.4 & $0.71(0.146)$ & 35 & 363.6 & $0.59(0.092)$ & 29 & 442.0 & $0.72(0.022)$ & 27 & 412.7 & $0.67(0.055)$ \\
\hline 06P851-(F5)-BSR-12 & 459.3 & $0.75(0.065)$ & 37 & 314.4 & $0.51(0.041)$ & 22 & 511.9 & $0.84(0.032)$ & 38 & 428.5 & $0.70(0.048)$ \\
\hline 06P847-(F5)-BSR-3 & 424.8 & $0.69(0.097)$ & 33 & 399.1 & $0.65(0.041)$ & 33 & 495.1 & $0.81(0.049)$ & 34 & 439.7 & $0.72(0.040)$ \\
\hline ATC 5336 & 443.3 & $0.72(0.101)$ & 36 & 533.4 & $0.87(0.039)$ & 39 & 495.6 & $0.81(0.075)$ & 35 & 490.8 & $0.80(0.043)$ \\
\hline ATC 859 & 521.8 & $0.85(0.029)$ & 40 & 504.9 & $0.82(0.055)$ & 37 & 471.6 & $0.77(0.056)$ & 31 & 499.4 & $0.82(0.027)$ \\
\hline ATC 36 & 472.5 & $0.77(0.032)$ & 38 & 508.8 & $0.83(0.052)$ & 38 & 539.6 & $0.88(0.035)$ & 40 & 507.0 & $0.83(0.024)$ \\
\hline ATC 5347 & 512.6 & $0.84(0.032)$ & 39 & 593.1 & $0.97(0.015)$ & 40 & 477.1 & $0.78(0.100)$ & 32 & 527.6 & $0.86(0.037)$ \\
\hline Pathogen mean rank & 235.0 & & & 340.6 & & & 343.9 & & & & \\
\hline ERTE (SE) & $0.38(0.017)$ & & & $0.56(0.015)$ & & & $0.56(0.016)$ & & & & \\
\hline \multicolumn{12}{|c|}{ Analysis of variance-type statistic, one-way } \\
\hline & & $\mathrm{F}$ & $P$ value & & & & & & & & \\
\hline Significance among pat & logens & 27.16 & $<0.0001$ & & & & & & & & \\
\hline Significance among ger & otypes & 6.91 & $<0.0001$ & & & & & & & & \\
\hline \multicolumn{12}{|c|}{ Analysis of variance-type statistic, two-way } \\
\hline & & $\mathrm{F}$ & $P$ value & & & & & & & & \\
\hline Overall pathogens (1) & & 51.72 & $<0.0001$ & & & & & & & & \\
\hline Genotypes (2) & & 9.99 & $<0.0001$ & & & & & & & & \\
\hline Pathogens $\times$ Genotypes & & 2.45 & $<0.0001$ & & & & & & & & \\
\hline
\end{tabular}

${ }^{a}$ ERTE: Estimated relative treatment effect at $\alpha=0.05$.

b SE: Standard error. 
of field pea against multiple pathogens in the black spot complex, viz. D. pinodes, $A$. pisi, and $P$. pinodella, where some genotypes showed resistance against two of these pathogens. In particular, in that study, two field pea lines, viz. P.I.173052 and P.I.236493, showed combined resistance against $D$. pinodes, $P$. pinodella, and A. pisi for the majority of isolates tested (2).

Tran et al. (42) reported that the population of individual pathogens constituting the black spot complex is dynamic across time and geographic location. In addition, recently there have been some additional pathogens added to the black spot complex in Western Australia, including P. koolunga (42), P. herbarum (26), P. glomerata (44), and B. exigua var. exigua (25) besides the well-recognized highly virulent pathogens $D$. pinodes (7) and $P$. pinodella (33) in Western Australia, and $P$. koolunga there and elsewhere $(13,15,30)$. The combination of three factors, viz. (i) the diversity of the pathogens constituting the black spot complex, (ii) the changing of the relative individual pathogen proportions with time and between locations, and (iii) the difference in response of field pea genotypes to the individual pathogens in the complex, make developing field pea varieties resistant to the black spot complex extremely challenging. Until now, field pea breeding programs in Australia and elsewhere have mainly targeted resistance to $D$. pinodes $(1,6,18,23,35,50,52,53)$. If host resistance is developed predominantly against only $D$. pinodes, then deployment of such resistance is likely to result in a shift within the pathogen population toward other pathogens less challenged.

Another challenge for breeders is that stem and leaf resistances are controlled by different genes $(11,23)$. Results in our study showed that there was no significant correlation between disease on leaf and stem caused by $D$. pinodes (Spearman's rho $=-0.031, P=0.662$ ) or $P$. pinodella (Spearman's rho $=-0.109, P=0.121$ ), confirming earlier findings $(10,11)$. In a study on a wider collection of isolates of $D$. pinodes from Europe, Australia, South America, and South Africa using a qualitative scale based on microscopic studies of fungal hyphae growth in host cells, Clulow et al. (11) concluded that stem and leaf resistances were inherited independently (11). Gene Rmpl and Rmp2 (nonallelic) were identified and designated for stem resistance, whereas Rmp3 and Rmp4 were for the leaf resistance (11).

Screening for black spot resistance in field pea in Australia and elsewhere has largely focused on $D$. pinodes $(6,18,23,35,50,52,53)$, much less so on $P$. pinodella $(2,22,36)$, and not at all on P. koolunga. With field screening, it has not been clear exactly what the resistance is against, generally assuming it is against $D$. pinodes, but it may have been against $P$. pinodella or $P$. koolunga, individually or in some combination. In our study, eight genotypes showed resistance against two pathogens on stem, viz. Dundale, ATC 866, 34-2C, ATC 5345 (P. koolunga and P. pinodella), 05P778-BSR-701 (D. pinodes and P. koolunga), ATC 864, Austrian Winter Pea, and 98107-62E (D. pinodes and $P$. pinodella). Seven genotypes showed resistance against two pathogens on leaf, viz. Dundale ( $P$. koolunga and $P$. pinodella), 06P822-(F5)-BSR-7, 05P773-BSR-706, M 330-6 (D. pinodes and P. koolunga), Austrian Winter Pea, 05P803-BSR-701, and 9810762E (D. pinodes and $P$. pinodella). Moreover, two genotypes, viz. 35-2C and 05P773-BSR-706, showed resistance to all three pathogens on stem and leaf, respectively. Pea genotypes that showed combined resistance to more than one pathogen in the black spot complex are particularly important sources of resistance for pea breeding programs, not only in Australia, but also elsewhere.

While $P$. koolunga has only recently been identified in Australia $(13,27,42)$, it could have been present for some time but gone unnoticed. However, studies in Western Australia have confirmed that it is a recent introduction and only detected in 2012 at four minor field pea sites (42). It is possible that at least some of the other black spot field screening sites across Australia may not yet contain P. koolunga. While our study is the first to identify resistance to $P$. koolunga, the high level of virulence of Western Australian isolates suggests urgency for more studies to identity additional sources of host resistance. Our study identified that some genotypes show high level of resistance against $P$. koolunga. For example, on stem, the five most resistant genotypes were 05P778-BSR-701, ATC 5338, ATC 5345, Dundale, and ATC 866. On leaf, ATC 866 was the most resistant genotype.
It is noteworthy that combined leaf and stem resistance against $P$. koolunga has also been identified in ATC 866 (AUDPC $\mathrm{MR}=250.4, \mathrm{OR}=5$ and $\mathrm{AUDPC} \mathrm{MR}=155.9, \mathrm{OR}=1$ on stem and leaf, respectively) and Dundale (AUDPC MR $=216.8, \mathrm{OR}=4$ and AUDPC MR $=230.6, \mathrm{OR}=6$, on stem and leaf, respectively). The two genotypes will be important sources of resistance against $P$. koolunga for pea breeders.

Dundale was considered as a susceptible benchmark for $D$. pinodes resistance in southern Australia as reported by Adhikari et al. (1). Further, Gurung et al. (21) found Dundale very susceptible among 15 field pea genotypes screened against $D$. pinodes, and as did Timmerman-Vaughan et al. (41). However, in this study, in spite of its low level of stem resistance (AUDPC MR $=199.9$, OR $=14$ ) and susceptibility to leaf disease (AUDPC MR $=193.6$, OR $=20$ ) against $D$. pinodes, Dundale displayed resistance in both stem and leaf against $P$. koolunga (AUDPC MR $=216.8, \mathrm{OR}=4$ on stem, and AUDPC MR $=230.6, \mathrm{OR}=6$ on leaf) and $P$. pinodella (AUDPC $\mathrm{MR}=70.8, \mathrm{OR}=2$ on stem, and $\mathrm{AUDPC} \mathrm{MR}=221.9, \mathrm{OR}=8$ on leaf). This may explain why Dundale remained a mainstay of pea production in Western Australia (3) for considerable time. It is clear that rescreening the field pea lines/cultivars previously found to be susceptible to $D$. pinodes is now warranted in the search for better levels of resistance against $P$. koolunga and $P$. pinodella. Further, in some situations, varieties like Dundale offer unique opportunities for breeding programs to simply add resistance against $D$. pinodes to the already existing resistance against $P$. koolunga and $P$. pinodella.

Davidson et al. (15), from studies conducted in 2008/2009, reported that DNA of $P$. koolunga was detected in soils cropped to field pea along with $D$. pinodes and $P$. pinodella in New South Wales, South Australia, Victoria, and Western Australia; and noted that it was common to detect $P$. koolunga in soil in South Australia, but rare in the other states in Australia. Findings of Tran et al. (42) added support to the claim of Davidson et al. (15) that $P$. koolunga "may become more widespread in future years," confirming this was indeed the case in Western Australia. Since the 2008 to 2009 growing seasons in Western Australia, P. koolunga has become widely established outside the Katanning and Esperance regions into the Nyabing, Dalwallinu, and Northam regions. Clearly, P. koolunga is rapidly spreading across Western Australia and likely so elsewhere in Australia, elevating it to an important pathogen status within the black spot complex. It is noteworthy that in our study, $P$. koolunga was the most virulent of the three pathogens in terms of stem disease, and its AUDPC MR was significantly higher than that of $D$. pinodes, previously considered the most important pathogen in the black spot complex $(31,32)$.

In conclusion, this study is the first to identify genotypes with resistance to $P$. koolunga and also the first to identify combined resistance against $P$. koolung $a$ and another pathogen of the complex. This and other combined resistances identified are of particular significance to breeding programs. It is clear that response of field pea genotypes vary widely depending upon the pathogen, but also upon stem versus leaf. This, along with the fact that so few genotypes displayed resistance against multiple pathogens, explains why field pea varieties arising from breeding programs in Australia fail to display the level or consistency of resistance sought. Further, this study shows that the Australian breeding programs cannot simply remain focused on resistance against $D$. pinodes while ignoring other pathogens of the complex, particularly $P$. koolung $a$. Moreover, deployment of host resistance developed historically in Australia, that targets only part of the pathogen complex, in itself would likely shift the makeup of the population toward pathogen species least challenged by that particular host resistance. It is essential that field pea breeding programs now need to accommodate the dynamic pathogen populations over time and location, and the inherent wider diversity of pathogens in the black spot complex. This is a huge challenge as no complete resistance has been reported to this date. It is now clear as to why black spot on field pea remains the most devastating disease despite enormous efforts and resources invested on breeding for resistance in the past. 


\section{Acknowledgments}

The first author gratefully acknowledges the financial assistance of an Australian Government Postgraduate AUSAID Scholarship. We appreciate the operational funding support for this research provided by the School of Plant Biology at The University of Western Australia. We thank the Department of Agriculture and Food Western Australia and Dr. Bob Redden, Curator, Australian Temperate Field Crops Collection, Horsham, Victoria for supplying seed lines. We are most grateful to Dr. Katia Stefanova for her advice on statistical analyses.

\section{Literature Cited}

1. Adhikari, K. N., Khan, T. N., Stefanova, K., and Pritchard, I. 2014. Recurrent breeding method enhances the level of black spot (Didymella pinodes (Berk. \& Blox.)Vestergr.) resistance in field pea (Pisum sativum L.) in southern Australia. Plant Breed. 133:508-514

2. Ali, S. M., Nitschke, L. F., Dube, A. J., Krause, M. R., and Cameron, B. 1978. Selection of pea lines for resistance to pathotypes of Ascochyta pinodes, A. pisi and Phoma medicaginis var. pinodella. Aust. J. Agric. Res. 29:841-849.

3. Anonymous. 1999. Crop Updates 1999 - Field pea time of sowing. Available at http://archive.agric.wa.gov.au/PC_91428.html?s=1001 Department of Agriculture and Food Western Australia. South Perth, WA, Australia.

4. Beeck, C. P. 2006. Simultaneous improvement in black spot resistance and stem strength in field pea (Pisum sativum L.). PhD Thesis. The University of Western Australia, Nedlands, WA, Australia.

5. Beeck, C. P., Wroth, J., and Cowling, W. A. 2006. Genetic variation in stem strength in field pea (Pisum sativum L.) and its association with compressed stem thickness. Aust. J. Agric. Res. 57:193-199.

6. Beeck, C. P., Wroth, J. M., Falk, D. E., Khan, T. N., and Cowling, W. A. 2008. Two cycles of recurrent selection lead to simultaneous improvement in black spot resistance and stem strength in field pea. Crop Sci. 48: 2235-2244.

7. Bretag, T. W., Keane, P. J., and Price, T. V. 2006. The epidemiology and control of Ascochyta blight in field peas: a review. Aust. J. Agric. Res. 57: 883-902.

8. Burdon, J. J., and Chilvers, G. A. 1982. Host density as a factor in plant disease ecology. Annu. Rev. Phytopathol. 20:143-166.

9. Campbell, C. L., and Madden, L. V. 1990. Temporal analysis of epidemics. I. Description and comparison of disease progress curves. Pages 161-202 in: Introduction to Plant Disease Epidemiology. John Wiley \& Sons, New York.

10. Clulow, S. A., Lewis, B. G., and Matthews, P. 1991. A pathotype classification for Mycosphaerella pinodes. J. Phytopathol. 131:322-332.

11. Clulow, S. A., Matthews, P., and Lewis, B. G. 1991. Genetic analysis of resistance to Mycosphaerella pinodes in pea seedlings. Euphytica 58: 183-189.

12. Cousin, R. 1997. Peas (Pisum sativum L.). Field Crops Res. 53:111-130.

13. Davidson, J. A., Hartley, D., Priest, M., Herdina, M. K., McKay, A., and Scott, E. S. 2009. A new species of Phoma causes Ascochyta blight symptoms on field peas (Pisum sativum) in South Australia. Mycologia 101:120-128.

14. Davidson, J. A., and Kimber, R. B. E. 2007. Integrated disease management of Ascochyta blight in pulse crops. Eur. J. Plant Pathol. 119:99-110.

15. Davidson, J. A., Krysinska-Kaczmarek, M., Wilmshurst, C. J., McKay, A., Herdina, and Scott, E. S. 2011. Distribution and survival of Ascochyta blight pathogens in field pea cropping soils of Australia. Plant Dis. 95: 1217-1223.

16. FAOSTAT. 2014. Available at http://faostat3.fao.org/faostat-gateway/go/to/ download/Q/QC/E Accessed 19 June 2014.

17. Fondevilla, S., Almeida, N. F., Satovic, Z., Rubiales, D., Vaz Patto, M. C., Cubero, J. I., and Torres, A. M. 2011. Identification of common genomic regions controlling resistance to Mycosphaerella pinodes, earliness and architectural traits in different pea genetic backgrounds. Euphytica 182: 43-52.

18. Fondevilla, S., Avila, C. M., Cubero, J. I., and Rubiales, D. 2005. Response to Mycosphaerella pinodes in a germplasm collection of Pisum spp. Plant Breed. 124:313-315.

19. Fondevilla, S., Cubero, J. I., and Rubiales, D. 2007. Inheritance of resistance to Mycosphaerella pinodes in two wild accessions of Pisum. Eur. J. Plant Pathol. 119:53-58

20. Fondevilla, S., Küster, H., Krajinski, F., Cubero, J. I., and Rubiales, D. 2011. Identification of genes differentially expressed in a resistant reaction to Mycosphaerella pinodes in pea using microarray technology. BMC Genomics 12:28.

21. Gurung, A. M., Pang, E. C. K., and Taylor, P. W. J. 2002. Examination of Pisum and Lathyrus species as sources of Ascochyta blight resistance for field pea (Pisum sativum). Australas. Plant Pathol. 31:41-45.

22. Hillstrand, D. S., and Auld, D. L. 1982. Comparative evaluation of four techniques for screening winter peas for resistance to Phoma medicaginis var. pinodella. Crop Sci. 22:282-287.
23. Khan, T. N., Timmerman-Vaughan, G. M., Rubiales, D., Warkentin, T. D. Siddique, K. H. M., Erskine, W., and Barbetti, M. J. 2013. Didymella pinodes and its management in field pea: challenges and opportunities. Field Crops Res. 148:61-77.

24. Lackermann, K. V., Conley, S. P., Gaska, J. M., Martinka, M. J., and Esker, P. D. 2011. Effect of location, cultivar, and diseases on grain yield of soft red winter wheat in Wisconsin. Plant Dis. 95:1401-1406.

25. Li, Y. P., You, M. P., Finnegan, P. M., Khan, T. N., Lanoiselet, V., Eyres, N., and Barbetti, M. J. 2012. First report of black spot caused by Boerema exigua var. exigua on field pea in Australia. Plant Dis. 96:148.

26. Li, Y. P., You, M. P., Khan, T. N., Finnegan, P. M., and Barbetti, M. J. 2011 First report of Phoma herbarum on field pea (Pisum sativum) in Australia. Plant Dis. 95:1590.

27. Liu, J. F., Cao, T. S., Feng, J., Chang, K. F., Hwang, S. F., and Strelkov, S. E. 2013. Characterization of the fungi associated with Ascochyta blight of field pea in Alberta, Canada. Crop Prot. 54:55-64.

28. McDonald, G. K., and Peck, D. 2009. Effects of crop rotation, residue retention and sowing time on the incidence and survival of Ascochyta blight and its effect on grain yield of field peas (Pisum sativum L.). Field Crops Res. 111:11-21.

29. McMurray, L. S., Davidson, J. A., Lines, M. D., Leonforte, A., and Salam, M. U. 2010. Combining pathological, agronomic and breeding advances to maximise Pisum sativum yields under changing climatic conditions in South-Eastern Australia. Proceedings of the 5th International Research Conference, April 2010, Antalya, Turkey.

30. McMurray, L. S., Davidson, J. A., Lines, M. D., Leonforte, A., and Salam, M. U. 2011. Combining management and breeding advances to improve field pea (Pisum sativum L.) grain yields under changing climatic conditions in south-eastern Australia. Euphytica 180:69-88.

31. Moussart, A., Tivoli, B., Lemarchand, E, Deneufbourg, F, Roi, S, and Sicard, G. 1998. Role of seed infection by the Ascochyta blight pathogen of dried pea (Mycosphaerella pinodes) in seedling emergence, early disease development and transmission of the disease to aerial plant parts. Eur. J. Plant Pathol. 104:93-102.

33. Onfroy, C., Tivoli, B., Corbiere, R., and Bouznad, Z. 1999. Cultural, molecular and pathogenic variability of Mycosphaerella pinodes and Phoma medicaginis var. pinodella isolates from dried pea (Pisum sativum) in France. Plant Pathol. 48:218-229.

32. Onfroy, C., Baranger, A., and Tivoli, B. 2007. Biotic factors affecting the expression of partial resistance in pea to ascochyta blight in a detached stipule assay. Eur. J. Plant Pathol. 119:13-27.

34. Peck, D., McDonald, G., and Davidson, J. A. 2001. Blackspot survival in soil and stubble and aerial dissemination through the season. Page 147 in: 10th Australian Agronomy, Hobart, Tasmania.

35. Prioul, S., Frankewitz, A., Deniot, G., Morin, G., and Baranger, A. 2004 Mapping of quantitative trait loci for partial resistance to Mycosphaerella pinodes in pea (Pisum sativum L.), at the seedling and adult plant stages. Theor. Appl. Genet. 108:1322-1334.

36. Sakar, D., Muehlbauer, F. J., and Kraft, J. M. 1982. Techniques of screening peas for resistance to Phoma medicaginis var. pinodella. Crop Sci. 22:988-992.

37. Salam, M. U., Galloway, J., MacLeod, W. J., Davidson, J. A., Seymour, M., Pritchard, I., Salam, K. P., Diggle, A. J., and Maling, T. 2011. G1 Blackspot Manager model predicts the maturity and release of ascospores in relation to Ascochyta blight on field pea. Australas. Plant Pathol. 40:621-631.

38. Setti, B., Bencheikh, M., Henni, J., and Neema, C. 2009. Comparative aggressiveness of Mycosphaerella pinodes on peas from different regions in western Algeria. Phytopathol. Mediterr. 48:195-204.

39. Setti, B., Bencheikh, M., Henni, J., and Neema, C. 2011. Morphological and virulence variation among isolates of Mycosphaerella pinodes the causal agent of pea leaf blight. Afr. J. Agr. Res. 6:1067-1075.

40. Shah, D., and Madden, L. 2004. Nonparametric analysis of ordinal data in designed factorial experiments. Phytopathology 94:33-43.

41. Timmerman-Vaughan, G. M., Frew, T. J., Butler, R., Murray, S., Gilpin, M., Falloon, K., Johnston, P., Lakeman, M. B., Russell, A., and Khan, T. 2004 Validation of quantitative trait loci for Ascochyta blight resistance in pea (Pisum sativum L.), using populations from two crosses. Theor. Appl. Genet. 109:1620-1631.

42. Tran, H. S., Li, Y. P., You, M. P., Khan, T. N., Pritchard, I., and Barbetti, M. J 2014. Temporal and spatial changes in the pea black spot disease complex in Western Australia. Plant Dis. 98:790-796.

43. Tran, H. S., You, M. P., Khan, T. N., Pritchard, I., and Barbetti, M. J. 2014 Resistance in field pea (Pisum sativum) to the black spot disease complex in Western Australia. Eur. J. Plant Pathol. 140:597-605.

44. Tran, H. S., You, M. P., Li, Y. P., Lanoiselet, V., Khan, T. N., and Barbetti, M. J. 2014. First report of Phoma glomerata on field pea (Pisum sativum) in Australia Plant Dis. 98:427.

45. Vale, F. X. R., Parlevliet, J., and Zambolim, L. 2001. Concepts in plant disease resistance. Fitopatol. Bras. 26:577-589.

46. Wallen, V. R., Cuddy, T. F., and Grainger, P. N. 1967. Epidemiology and control of Ascochyta pinodes on field peas in Canada. Can. J. Plant Sci. 47: 395-403.

47. Warkentin, T. D., Rashid, K. Y., and Xue, A. G. 1996. Fungicidal control of Ascochyta blight of field pea. Can. J. Plant Sci. 76:67-71. 
48. Warkentin, T. D., Xue, A. G., and McAndrew, D. W. 2000. Effect of mancozeb on the control of Mycosphaerella blight of field pea. Can. J. Plant Sci. 80:403-406.

49. Wroth, J. M. 1996. Host-pathogen relationships of the Ascochyta blight (Mycosphaerella pinodes (Berk. \& Blox.) Vestergr.) disease of pea (Pisum sativum L.). PhD Thesis. The University of Western Australia, Nedlands, WA, Australia.

50. Wroth, J. M. 1998. Possible role for wild genotypes of Pisum spp. to enhance Ascochyta blight resistance in pea. Aust. J. Exp. Agric. 38:469-479.
51. Wroth, J. M. 1998. Variation in pathogenicity among and within Mycosphaerella pinodes populations collected from field pea in Australia. Can. J. Bot. 76:1955-1966.

52. Xue, A. G., and Warkentin, T. D. 2001. Partial resistance to Mycosphaerella pinodes in field pea. Can. J. Plant Sci. 81:535-540.

53. Zhang, R., Hwang, S. F., Chang, K. F., Gossen, B. D., Strelkov, S. E. Turnbull, G. D., and Blade, S. F. 2006. Genetic resistance to Mycosphaerella pinodes in 558 field pea accessions. Crop Sci. 46:2409-2414. 